\title{
Immunologic and Hematopoietic Effects of CD40 Stimulation After Syngeneic Bone Marrow Transplantation in Mice
}

\author{
S. Funakoshi, ${ }^{\star}$ D.D. Taub, ${ }^{\ddagger}$ M.R. Anver, ${ }^{\S}$ A. Raziuddin,, O. Asai, ${ }^{\star}$ V. Reddy, ${ }^{\|}$H. Rager, ${ }^{\ddagger}$ W.C. Fanslow, ${ }^{\Uparrow "}$ D.L. Longo, \\ and W.J. Murphy \\ *Laboratory of Leukocyte Biology, Biological Response Modifiers Program, Division of Cancer Treatment, National Cancer Institute \\ Frederick Cancer Research and Development Center (NCI-FCRDC), the Intramural Research Support Program, ${ }^{\S}$ Pathology/ \\ Histotechnology, ${ }^{\ddagger}$ Clinical Sciences Program and Laboratory of Animal Science Programs, Science Applications International \\ Corporation-Frederick, NCI-FCRDC, Frederick, Maryland 21702; and "Immunex Corp., Seattle, Washington 98101
}

\begin{abstract}
CD40 is a molecule present on multiple cell types including B lymphocyte lineage cells. CD40 has been shown to play an important role in $B$ cell differentiation and activation in vitro, although little is known concerning the effects of CD40 stimulation in vivo. We therefore examined the effects of CD40 stimulation in mice using a syngeneic bone marrow transplantation (BMT) model in an effort to augment B cell recovery after high dose therapy with hematopoietic reconstitution. After the BMT, mice were treated with or without 2-6 $\mu \mathrm{g}$ of a soluble recombinant murine CD40 ligand (srmCD40L) given intraperitoneally twice a week. A significant increase in $\mathrm{B}$ cell progenitors $\left(\mathrm{B}_{220}{ }^{+}\right.$I surface $\operatorname{IgM}^{-}$) was observed in the bone marrow of mice receiving the srmCD40L. The treated recipients also demonstrated improved B-cell function with increases in total serum immunoglobulin and increased splenic mitogen responsiveness to LPS being noted. Additionally, srmCD40L treatment promoted secondary lymphoid organ repopulation, accelerating germinal center formation in the lymph nodes. Total B cell numbers in the periphery were not significantly affected even with continuous srmCD40L administration. Lymphocytes obtained from mice treated with the ligand also had increases in $\mathrm{T}$ cell mitogen and anti-CD3 $\mathrm{mAb}$ responsiveness and acquired the capability to produce IL-4. Surprisingly, treatment with srmCD40L also produced hematopoietic effects in mice, resulting in an increase of $\mathrm{BM}$ and splenic hematopoietic progenitor cells in the mice after BMT. Treatment with srmCD40L significantly increased granulocyte and platelet recovery in the peripheral blood. Incubation of BMC with srmCD40L in vitro also resulted in increased progenitor proliferation, demonstrating that the hematopoietic effects of the ligand may be direct. Thus, stimulation of CD40 by its ligand may be beneficial in accelerating both immune and hematopoietic recovery in the setting of bone marrow transplantation. ( $J$. Clin. Invest. 1997. 99:484-491.) Key words: bone marrow transplantation - CD40 - immune - hematopoietic • engraftment
\end{abstract}

Address correspondence to William J. Murphy, IRSP, SAIC-Frederick, NCI-FCRDC, Building 567, Room 141, Frederick, MD 21702. Phone: 301-846-5443; FAX: 301-846-6107.

Received for publication 10 July 1996 and accepted in revised form 15 November 1996.

The Journal of Clinical Investigation

Volume 99, Number 3, February 1997, 484-491

\section{Introduction}

The prognosis of patients undergoing bone marrow transplantation $(\mathrm{BMT})^{1}$ is critically dependent on reconstitution of the hematopoietic system. The recovery of immunity after marrow transplantation is a complex process dependent on pre- and posttransplant factors $(1,2)$. Therapy used to prepare marrow graft recipients for infusion of donor marrow ablates the existing immunohematopoietic marrow elements. This intensive therapy creates a prolonged period of immune deficiency. Hematopoietic growth factors are now clinically used to accelerate neutrophil recovery (3), and several cytokines (including IL-2) are being investigated for the enhancement of cell-mediated immunity, and to reverse the deficiency of humoral immunity (4).

CD40 is a $55-\mathrm{kD}$ molecule present on the surface of B cells that appears to play a critical role in their growth and development (5-7). CD40 is a member of the nerve growth factor/TNF receptor family (8) and is present on a variety of cell types, including B cells, monocytes (9), dendritic cells (10), and some carcinoma cells (11). Antibodies to CD40 have been demonstrated to exert both stimulatory and differentiation responses in human B cells in vitro $(7,12,13)$. However, little is known concerning the effects of CD40 stimulation in vivo. The ligand for CD40 is expressed on activated T cells $(14,15)$. Individuals congenitally lacking this ligand (hyper IgM syndrome) have been shown to have a deficiency in circulating $\mathrm{IgG}$ antibodies $(16,17)$. In addition, antibodies to the ligand have been shown to block germinal center formation in mice and to inhibit $\mathrm{T}$ cell-dependent antibody responses $(18,19)$; and CD40 knockout mice have deficiencies in $\mathrm{IgG}$ production and germinal center development (20). Recently, a soluble recombinant version of the naturally occurring ligand for CD40 (srCD40L) was generated and found to stimulate B cell proliferation and function in vitro (21-23). We therefore evaluated the effects of soluble recombinant murine CD40 ligand (srmCD40L) on B cell recovery in a murine syngeneic BMT model. We report here that treatment of mice with srmCD40L after syngeneic BMT accelerates B and $\mathrm{T}$ cell recovery and unexpectedly improves hematopoietic engraftment.

\section{Methods}

Mice. C57BL/6 (B6) mice were obtained from the Animal Production Area (NCI-FCRDC, Frederick, MD) and were not used until 8 wk of age.

1. Abbreviations used in this paper: $\mathrm{BMC}$, bone marrow cells; BMT, bone marrow transplantation; ABMT, autologous BMT; Con A, concanavalin-A; GVHD, graft-vs.-host disease; SC, spleen cells; srmCD40L, soluble recombinant murine CD40 ligand. 
Bone marrow transplantation. Recipient B6 mice were exposed to a ${ }^{137} \mathrm{Cs} \gamma$ irradiation source. The mice received $1,050 \mathrm{cGy}$ total irradiation. Mice then received $10^{6}$ syngeneic bone marrow cells (BMC) intravenously. Either recombinant soluble murine CD40 ligand (2 or $6 \mu \mathrm{g}$ ) or HBSS with glycerol and normal mouse sera (control) were administered intraperitoneally twice a week starting at day 1 , until the harvest of the mice on days 8,15, and 22. All experiments were assayed with 4-5 mice/group and were performed five times with a representative experiment being shown.

Assay for in vitro hematopoiesis. BMC and spleen cells (SC) from mice 7, 14, and $22 \mathrm{~d}$ after BMT were washed and resuspended in Iscove's modified Dulbecco's medium (IMDM) with 15\% FBS, 1\% L-glutamine, $2 \times 10^{-5} \mathrm{M}$ 2-mercaptoethanol, and antibiotics (complete IMDM). SC were plated at $10^{6}$ cells/plate, and BMC were plated at $2 \times 10^{5}$ cells/plate. Both SC and BMC were plated with $0.35 \%$ Sea Plaque (FMC BioProducts, Rockland, ME) in $35-\times 10-\mathrm{mm}$ plates with grid (Nunc, Inc., Naperville, IL). Colony growth was stimulated with optimal doses of the growth-promoting cytokines recombinant mouse GM-CSF, $10 \mathrm{ng} / \mathrm{ml}$, and recombinant mouse IL-3, 10 $\mathrm{ng} / \mathrm{ml}$, supplied by the Biological Response Modifiers Program Repository (NCI-FCRDC). Plates were incubated at $37^{\circ} \mathrm{C}, 5 \% \mathrm{CO}_{2}$, and $100 \%$ humidity for $7 \mathrm{~d}$. In the experiments where the effects of the ligand were examined in vitro, BMC were incubated with different concentrations of the ligand with GM-CSF and IL-3. The plates were then examined for colonies, where $>50$ cells constituted a colony.

Analysis of peripheral blood. For analysis of peripheral blood (PB), blood was collected from the lateral tail vein of the mice using EDTA as an anticoagulant. Complete blood counts were performed with an HC820 (DANAM Electronics, Inc., Dallas, TX), and differential cell counts were performed by microscopic examination of Wright's standard PB-stained smears (MetPath, Inc., Rockville, MD).

Statistical analysis. A Student's $t$ test was performed to determine if values were significantly different $(P<0.05)$.

Serum immunoglobulin determination. For determination of total serum Ig, samples were assayed by ELISA as follows: flat bottom 96-well microtiter plates (Corning Glass Works, Corning, NY) were coated with goat anti-mouse Ig (Kirkegaard \& Perry Laboratories, Inc., Gaithersburg, MD) at $1 \mathrm{mg} / \mathrm{ml}$ in PBS. After washing two times, a blocking step was carried out using $5 \%$ goat serum. This was followed by the addition of titrations of mouse IgM + IgG standard (Dako Corp., Santa Barbara, CA). After washing four times, alkaline phosphatase-conjugated goat anti-mouse Ig (Kirkegaard \& Perry Laboratories, Inc.) was added. After washing, the reaction was developed using substrate and OD measured at $402 \mathrm{~nm}$. A Wilcoxon rank sum test was used to determine if the values differed significantly $(P<0.01)$.

Mitogen responsiveness assay. Single cell suspensions were prepared from the spleens of recipient mice. Triplicate cultures of $5 \times$ $10^{5}$ spleen cells and/or lymph node cells were incubated with $32 \mu \mathrm{g} / \mathrm{ml}$ of LPS, $10 \mu \mathrm{g} / \mathrm{ml}$ of Concanavalin A, or $200 \mathrm{ng} / \mathrm{ml}$ of anti-CD3 (2C11; PharMingen, San Diego, CA) in a final volume of $0.2 \mathrm{ml}$ RPMI 1640 supplemented with $10 \%$ fetal calf serum, $4 \mathrm{mM}$ glutamine, $19 \mathrm{mM}$ Hepes, $0.05 \mathrm{mM}$ 2-mercaptoethanol, $100 \mathrm{U} / \mathrm{ml}$ penicillin, and $100 \mu \mathrm{g} / \mathrm{ml}$ streptomycin for $48 \mathrm{~h}$ at $37^{\circ} \mathrm{C}$ in $5 \% \mathrm{CO}_{2}$. After $48 \mathrm{~h}$ of culture, the plates were pulsed with $1 \mathrm{uCi}$ of $\left[{ }^{3} \mathrm{H}\right]$ thymidine $(6.7 \mathrm{Ci} / \mathrm{mmol}$;DuPont-NEN, Boston, MA) per well for the final 18-24 h of incubation, and then harvested onto glass fiber filters. The amount of radiolabel incorporated was determined by liquid scintillation counting.

Quantitation of murine cytokines. Murine IL-4 and IFN $\gamma$ levels within the stimulated and control supernatants were determined by ELISA, using biotinylated and nonbiotinylated anti-murine IL-4 and IFN $\gamma$ antibodies obtained from R\&D Systems, Inc. (Minneapolis, MN).

Flow cytometric analysis. BMC, SC, or lymph node cells (inguinal, brachial, and mesenteric) were obtained from the mice 8, 15, and $22 \mathrm{~d}$ after syngeneic BMT. A single cell suspension was made and the cells were counted on a Coulter Counter (Coulter Electronics, Hialeah, FL). The cells were then adjusted to $10^{6}$ cells per $\mathrm{ml}$ and were blocked with an anti-mouse Fc receptor antibody (2.4G2, rat IgG1) to prevent nonspecific binding of immunoglobulin. The cells were then incubated with the appropriate directly labeled antibodies. The antibodies used were: B220 (6B2, directed against a murine B cell marker), 8C5 (directed against a marker found on murine granulocytes) from PharMingen, and goat anti-mouse IgM from Fisher Scientific Co. (Pittsburgh, PA). After incubation, the cells were washed and then fixed with $1 \%$ paraformaldehyde and the cells were analyzed using an EPICS flow cytometer (Coulter Electronics). The total number of cells present in the organ was determined by multiplying the percentage of cells present by the cellularity of the organ.

Histology. Lymph nodes were fixed in $10 \%$ formalin, embedded in paraffin, sectioned at $5 \mu \mathrm{m}$, and stained with hematoxylin and eosin. Slides were then evaluated microscopically for the presence of follicles and germinal centers without knowledge of the experimental treatment. Grading was as follows: 1, minimal; 2, mild; 3, moderate; 4, extensive; M, missing; P, present; -, no significant lesion; $\mathrm{F}$, focal; MF, multifocal; D, diffuse.

\section{Results}

Effects of srmCD40L on engraftment of syngeneic B220-positive cells in lethally irradiated recipients. Syngeneic BMC were

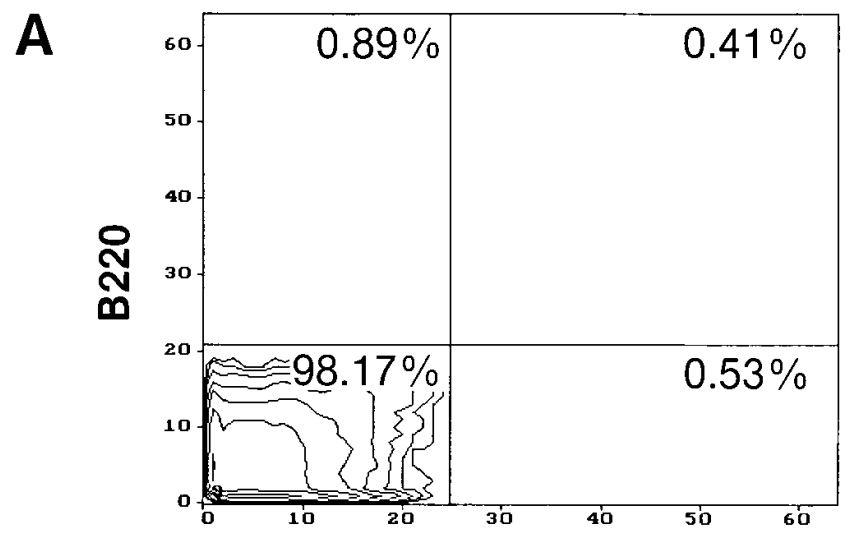

B

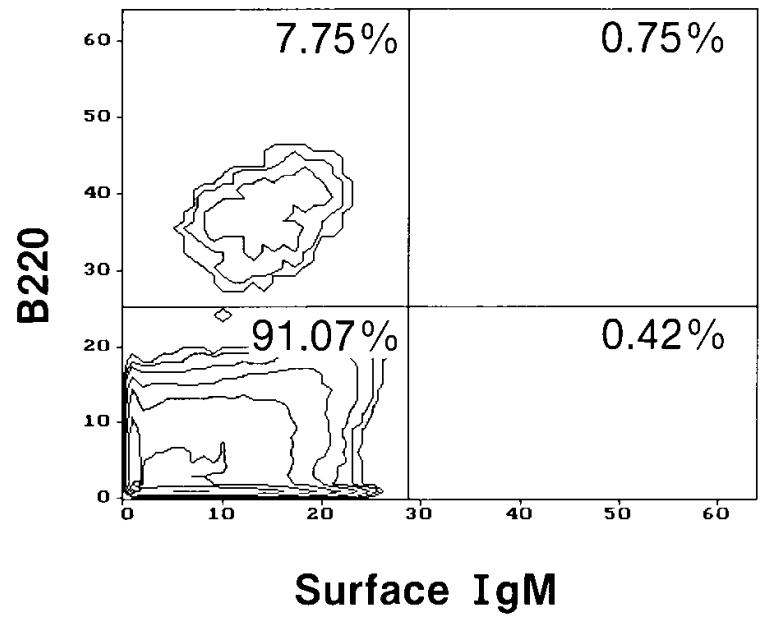

Figure 1. $\mathrm{B} 220^{+} /$surface $\mathrm{IgM}^{-} \mathrm{B}$ cell progenitors in the bone marrow from recipient mice in different groups, day 8 after syngeneic BMT as determined by flow cytometric analysis as described in Methods. After receiving 1,050 cGy total irradiation, mice then were injected with $10^{6} \mathrm{BMC}$ i.v. Either control sera + glycerol $(A)$ or $2 \mu \mathrm{g}$ of srmCD $40 \mathrm{~L}$ $(B)$ were administered i.p. twice a week starting at day 1 until the harvest. 

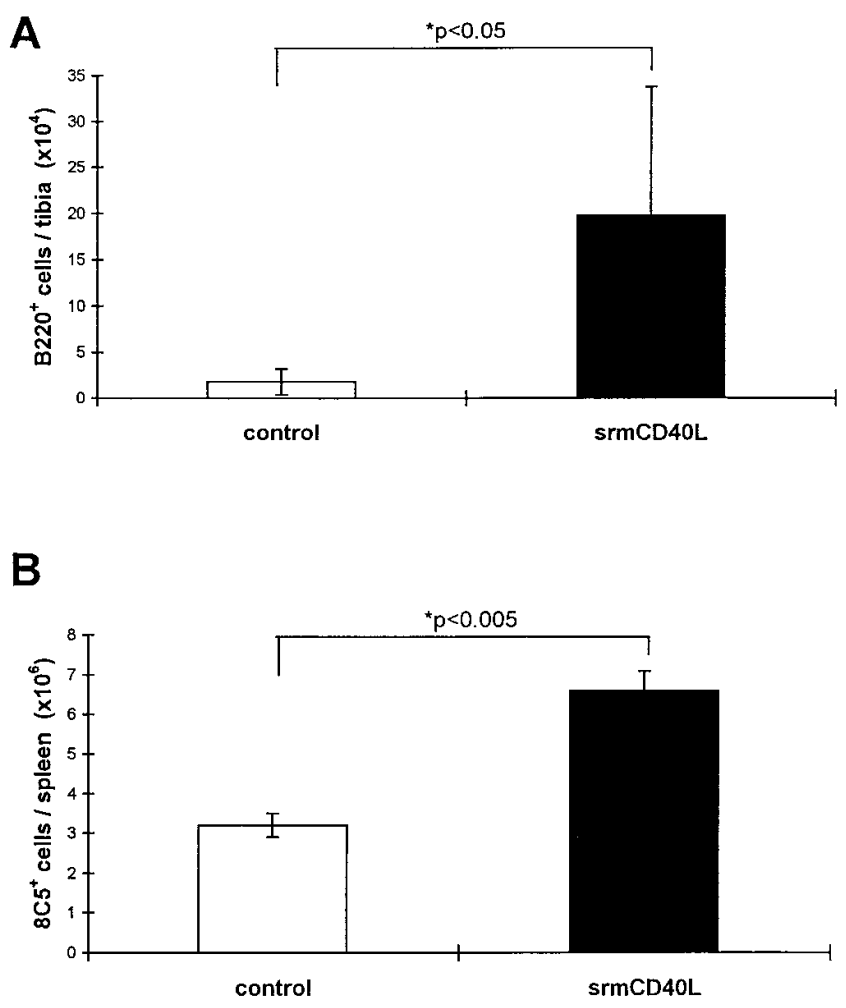

Figure 2. Effect of srmCD40L on $(A) \mathrm{B} 220^{+}$cell recovery in the BM, and $(B) 8 C 5^{+}$cell recovery in the spleen $7 \mathrm{~d}$ after syngeneic BMT.

transferred into lethally irradiated recipients to determine the effects of srmCD40L on B cell reconstitution. Either 2-6 $\mu \mathrm{g}$ of srmCD40L or control sera and glycerol was administered every $3 \mathrm{~d}$ starting at day 1 . Reconstitution of $\mathrm{B}$ cell progenitors in the $\mathrm{BM}$ and spleen was assessed by flow cytometric analysis. The results demonstrate that treatment with srmCD40L significantly increased B cell progenitors $\left(\mathrm{B} 220^{+} /\right.$surface $\left.\operatorname{IgM}^{-}\right)$in the $\mathrm{BM}$ when the mice were examined $8 \mathrm{~d}$ after BMT, compared with mice in groups not receiving srmCD40L (Fig. 1). There was an increase in $\mathrm{B}_{2} 20^{+} /$surface $\mathrm{IgM}^{-}$cells, representing $\mathrm{B}$ cell progenitors, in recipient mouse bone marrow $8 \mathrm{~d}$ after BMT. The total number of the bone marrow cells positive for B220 also increased (Fig. $2 A$ ). Interestingly, at later time points, no increases of mature B cells $\left(\mathrm{B} 220^{+} /\right.$surface $\left.\operatorname{IgM}^{+}\right)$ were detected in the BM or spleen in groups receiving continuous treatment with srmCD40L (data not shown). Thus, CD40 stimulation after BMT resulted in increased numbers of B cell progenitors in the $\mathrm{BM}$, but this did not translate into significantly increased production of mature B cells in the periphery.

Effects of srmCD40L on B and T cell function after syngeneic BMT. We then determined total serum Ig levels by ELISA as a parameter for mature B cell function. The data demonstrated that treatment with srmCD40L resulted in increased serum IgM production on day 14 after BMT (Fig. 3). Thus, CD40 stimulation by the soluble ligand resulted in increased serum IgM production in the first 2 wk after BMT; serum $\mathrm{IgG}$ levels were not significantly different.

We also examined effects on B cell function as reflected by mitogen responses of murine splenic and lymph node cells to LPS. Treatment of mice with srmCD40L significantly increased both splenic and lymph node cell responsiveness to

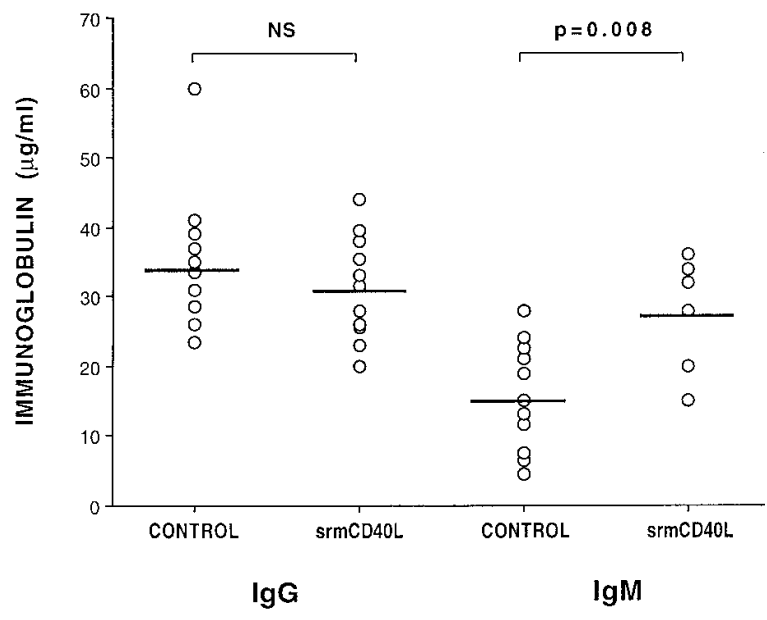

Figure 3. Effects of srmCD40L on the production of $\mathrm{IgG}$ and $\operatorname{IgM}$ in mice $14 \mathrm{~d}$ after syngeneic BMT as determined by ELISA as described in Methods. The results are expressed in optical density units as assessed on a spectrophotometer at $402 \mathrm{~nm}$ from 1:100 dilution of each sample. SrmCD40L significantly $(P<0.01)$ increased the production of IgM.

LPS when assessed $10 \mathrm{~d}$ after BMT (Fig. 4). However, since there was no significant difference in the numbers of splenic mature $\left(\mathrm{B} 220^{+} /\right.$surface $\left.\mathrm{IgM}^{+}\right) \mathrm{B}$ cells between mice in the control and treated groups, this suggests that CD40 stimulation primarily affected the function but not number of splenic $\mathrm{B}$ cells. Interestingly, we also found that mitogen responses of murine splenic cells to the $\mathrm{T}$ cell mitogen concanavalin-A (Con A) and anti-CD3 were significantly increased in the mice treated with srmCD40L, suggesting CD40 stimulation also affects $\mathrm{T}$ cell function (Fig. 4). Total $\mathrm{T}$ cell numbers were also not affected by treatment with the ligand. We then assessed the effects of ligand treatment on the capacity of splenocytes and lymph node cells to produce interferon $\gamma$ and IL-4 after stimulation with Con A. The results demonstrated that treatment with the ligand after BMT results in an increased ability of mitogen stimulated splenic and lymph node $\mathrm{T}$ cells to produce IL-4 (Fig. 5). Interferon $\gamma$ levels also appeared to be affected slightly, but this was not statistically significant. Thus, treatment of mice with srmCD40L resulted in increases in $\mathrm{T}$ cell function after BMT.

Effects of srmCD40L on germinal center reconstitution in lymph node after syngeneic BMT. We then investigated the effect of srmCD40L on reconstitution of secondary lymphoid organs. Lymphocyte development occurs not only within bone marrow, but also within peripheral lymphoid compartments. Treatment with srmCD40L dramatically promoted germinal center formation in the lymph nodes of recipients compared with those of control mice $8 \mathrm{~d}$ after BMT. When B220 ${ }^{+} /$surface $\mathrm{IgM}^{+}$cells in the lymph nodes of recipients were determined by flow cytometry, the lymph nodes of mice treated with srmCD40L contained significantly higher numbers of mature $B$ cells than did control mice (control, 1.52 $\pm 0.32 \times 10^{4}$ cells; treated, $4.22 \pm 1.04 \times 10^{4}$ cells; $P=0.047$ ), reflecting the acceleration of germinal center (GC) reconstitution. We then determined the time course of the germinal center formation affected by srmCD40L (Table I, Fig. 6). Stimulation by srmCD40L accelerated germinal center formation (days 8 and 14 after 


\section{A Spleen}
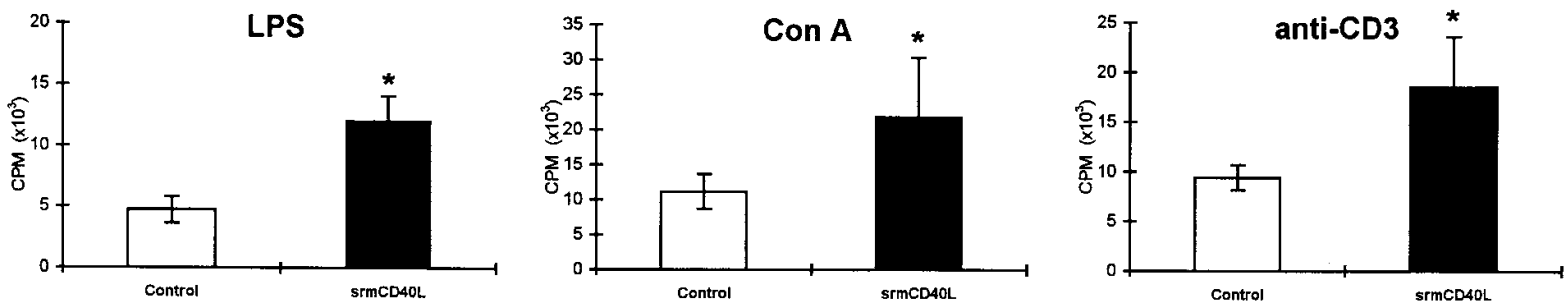

\section{B Lymph Node}
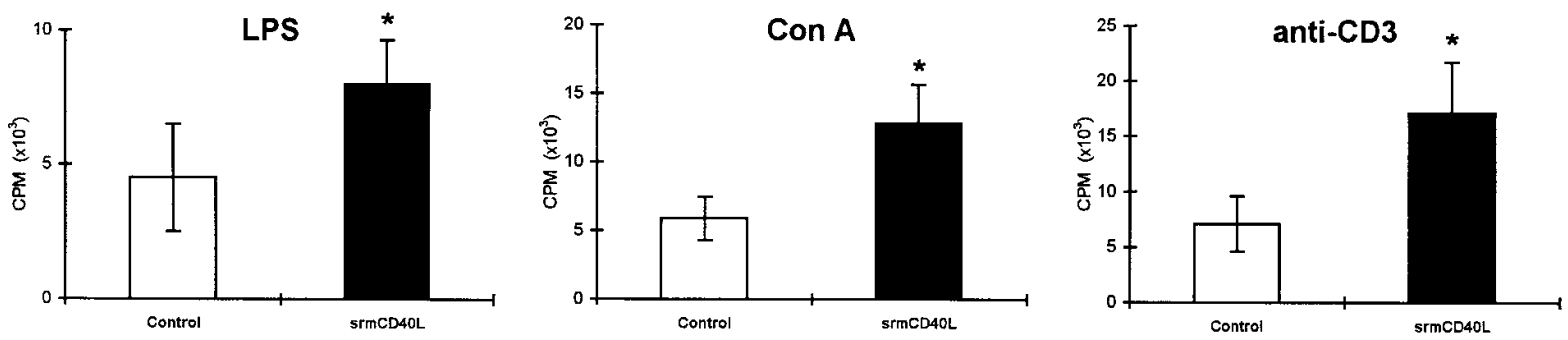

Figure 4. Effects of srmCD40L on mitogen responsiveness in different time points after syngeneic BMT as described in Methods. $10 \mathrm{~d}$ after BMT, splenocytes and lymph node cells were assessed for their response to various doses of LPS, Con A, and anti-CD3 in vitro. However, in this figure, only the $10 \mu \mathrm{g}$ LPS, $10 \mu \mathrm{g}$ Con A, and $1 \mu \mathrm{g}$ anti-CD3 were shown. Treatment with the ligand resulted in significant $(P<0.05)$ increases in proliferative responses.

BMT). However, the differences between control and treated mice were not significant by day 21 (Table I). The stimulatory effects of CD40L on peripheral B cell reconstitution were greatest in the first $2 \mathrm{wk}$ after the transplantation.

Effects of srmCD40L on the recovery of hematopoietic precursors after syngeneic BMT. We also investigated the effects of srmCD40L treatment on hematopoiesis after syngeneic BMT. The results showed that treatment with srmCD40L significantly $(P<0.05)$ increased splenic and BM hematopoietic progenitor content as assessed by in vitro CFU-C formation when compared with control mice (Table II). As with the effects on B cell recovery, the effects on hematopoietic parameters appeared to be greatest at earlier time points.

To ascertain if the growth-promoting effects of the ligand on hematopoiesis were directly due to the effects of the ligand on the hematopoietic progenitor cells, we incubated various concentrations of srmCD40L with BMC in vitro and assessed the effects on CFU-C formation. Incubation of BMC with the ligand alone produced no effects on CFU-C (Fig. 7). However, when the BMC were cultured with GM-CSF and IL-3, the ad-
Interferon $\gamma$

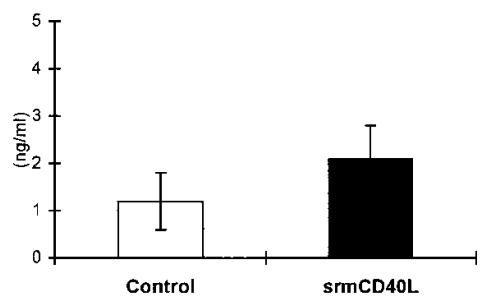

Spleen

\section{Lymph Node}

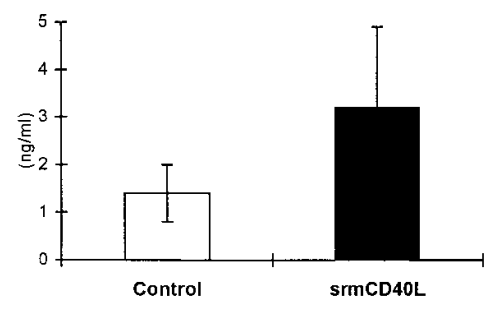

IL-4

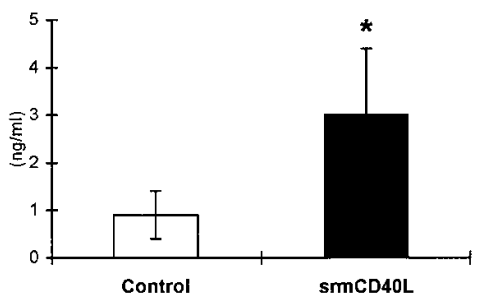

Figure 5. Effect of srmCD40L treatment on cytokine production by mitogen-activated spleen or lymph node cells. $10 \mathrm{~d}$ after BMT, $\mathrm{SC}$ and lymph node cells were activated with Con $A$ and $3 \mathrm{~d}$ later, ELISA assays specific for interferon $\gamma$ and IL-4 were performed on the supernatants. Values significantly greater $(P<0.01)$ than untreated recipients. 


\begin{tabular}{|c|c|c|c|c|c|}
\hline \multicolumn{2}{|l|}{ Day 8} & \multicolumn{2}{|l|}{ Day 14} & \multicolumn{2}{|l|}{ Day 21} \\
\hline Animal No. (treatment) & GCF & Animal No. (treatment) & GCF & Animal No. (treatment) & GCF \\
\hline 245 (Control) & - & 202 (Control) & $1 \mathrm{MF}$ & 275 (Control) & $1 \mathrm{MF}$ \\
\hline 246 (Control) & - & 203 (Control) & $1 \mathrm{MF}$ & 276 (Control) & $1 \mathrm{MF}$ \\
\hline \multirow[t]{3}{*}{247 (Control) } & - & 204 (Control) & - & & \\
\hline & & 205 (Control) & $1 \mathrm{~F}$ & & \\
\hline & & 206 (Control) & - & & \\
\hline $248(\operatorname{srmCD} 40 \mathrm{~L} 2 \mu \mathrm{g})$ & $1 \mathrm{~F}$ & $207(\operatorname{srmCD} 40 \mathrm{~L} 2 \mu \mathrm{g})$ & $2 \mathrm{MF}$ & 277 (srmCD40L $2 \mu \mathrm{g})$ & $1 \mathrm{MF}$ \\
\hline $249(\operatorname{srmCD} 40 \mathrm{~L} 2 \mu \mathrm{g})$ & $1 \mathrm{~F}$ & $208(\operatorname{srmCD} 40 \mathrm{~L} 2 \mu \mathrm{g})$ & $2 \mathrm{MF}$ & $278(\operatorname{srmCD} 40 \mathrm{~L} 2 \mu \mathrm{g})$ & $1 \mathrm{~F}$ \\
\hline \multirow[t]{3}{*}{$250($ srmCD 40L $2 \mu \mathrm{g})$} & $2 \mathrm{MF}$ & $209(\operatorname{srmCD} 40 \mathrm{~L} 2 \mu \mathrm{g})$ & $1 \mathrm{MF}$ & & \\
\hline & & $210(\operatorname{srmCD} 40 \mathrm{~L} 2 \mu \mathrm{g})$ & $1 \mathrm{MF}$ & & \\
\hline & & $211(\operatorname{srmCD} 40 \mathrm{~L} 2 \mu \mathrm{g})$ & $1 \mathrm{~F}$ & & \\
\hline
\end{tabular}

Grading by histological examination: 1, minimal; 2, mild; 3, moderate; 4, severe; -, no significant lesion; F, focal; MF, multifocal.

dition of srmCD40L produced significant increases in CFU-C formation. This suggests that CD40 stimulation may act as a costimulus in promoting hematopoietic growth.

We then determined the effects of srmCD40L treatment on both megakaryocytes and granulocytic precursors after BMT in mice. Actual numbers of megakaryocytes in spleens in each slide section were significantly higher in the treated mice compared with the control mice (treated, 83.2 \pm 11.3 ; control, 59.0 $\pm 8.9 ; P<0.05)$ as determined by histological assessment.
Phenotypic evaluation of the splenocytes through flow cytometric analysis indicated that there was also a significant increase in granulocyte precursors in the spleens of mice receiving srmCD40L as evidenced by the increased percentage and total amount of splenic $8 \mathrm{C} 5^{+}$cells, a surface marker present on granulocytic lineage cells (Fig. $2 \mathrm{~B}$ ). These results suggested that srmCD40L promoted the recovery of hematopoietic precursors, primarily affecting granulocytic and megakaryocytic lineages.
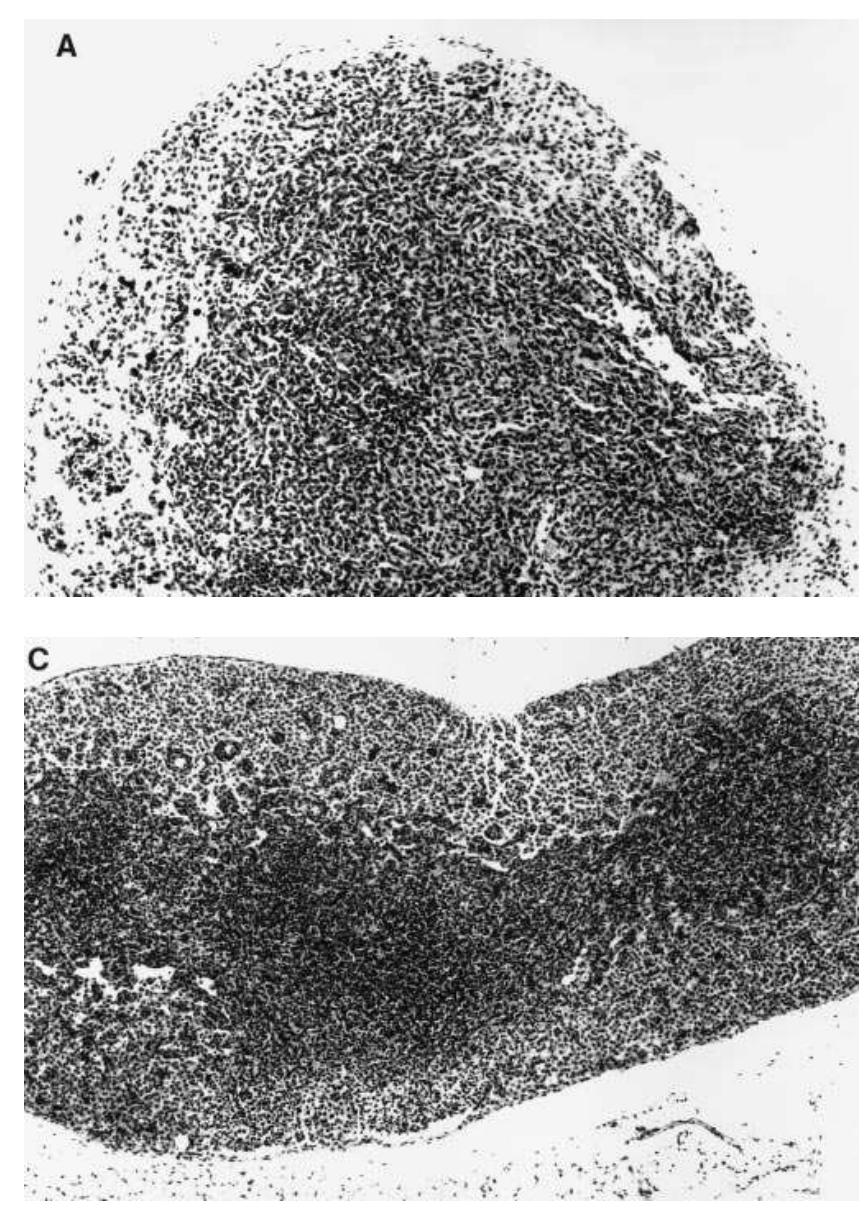

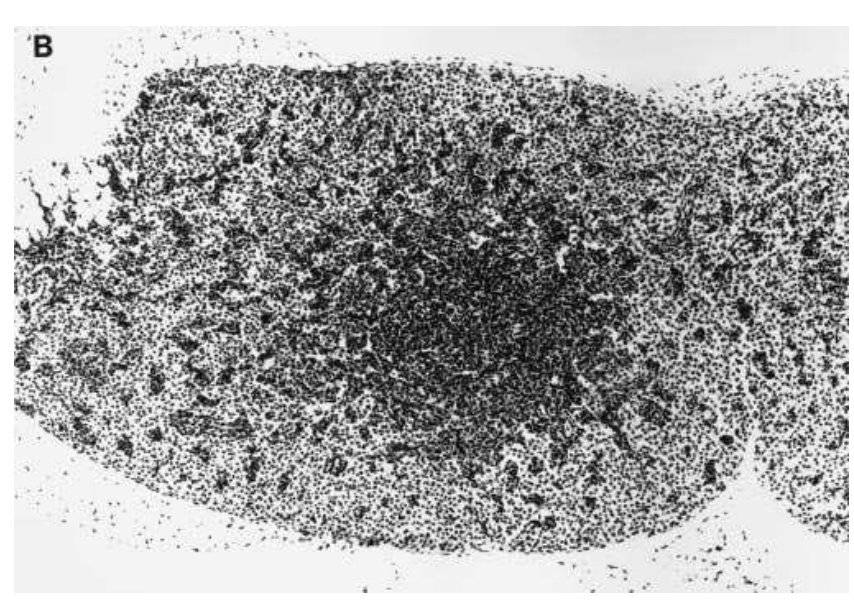

Figure 6. Histology of the lymph nodes of mice receiving either control sera + glycerol $(A)$ or $2 \mu \mathrm{g}$ of srmCD40L $(B$ and $C$ ). Histology was performed $8 \mathrm{~d}$ after syngeneic BMT as described in Methods. Note the reconstitution of germinal centers in the mice treated with $\operatorname{srmCD} 40 \mathrm{~L}(B$ and $C)$. $(40 \times)$ 
Table II. Effects of srmCD40L on CFU-C in Spleen and Bone Marrow After Syngeneic BMT

\begin{tabular}{|c|c|c|c|c|c|c|}
\hline \multirow[b]{2}{*}{ Experiment } & \multirow[b]{2}{*}{ Day of harvest } & \multirow[b]{2}{*}{ Treatment } & \multicolumn{2}{|c|}{ Total CFU-C/spleen } & \multicolumn{2}{|c|}{ Total CFU-C/BM (1 tibia + femur } \\
\hline & & & Cytokines & Media & Cytokines & Media \\
\hline \multirow[t]{2}{*}{ A } & \multirow[t]{2}{*}{7} & Control & $12.8 \pm 2.4$ & $0 \pm 0$ & $84.5 \pm 26.5$ & $0 \pm 0$ \\
\hline & & srmCD40L $2 \mu \mathrm{g}$ & $54.4 \pm 11.3^{*}$ & $0 \pm 0$ & $250.0 \pm 25.0 *$ & $0 \pm 0$ \\
\hline \multirow[t]{2}{*}{ B } & \multirow[t]{2}{*}{7} & Control & $27.4 \pm 15.9$ & $0 \pm 0$ & $992 \pm 256.8$ & $0 \pm 0$ \\
\hline & & srmCD40L $6 \mu \mathrm{g}$ & $49.2 \pm 2.9 *$ & $0 \pm 0$ & $2137 \pm 511.0$ & $0 \pm 0$ \\
\hline \multirow[t]{2}{*}{$\mathrm{C}$} & \multirow[t]{2}{*}{10} & Control & $288.0 \pm 110.0$ & $0 \pm 0$ & $215 \pm 62.8$ & $0 \pm 0$ \\
\hline & & srmCD40L $2 \mu \mathrm{g}$ & $604.3 \pm 65.3^{*}$ & $0 \pm 0$ & $454.1 \pm 69.6^{*}$ & $0 \pm 0$ \\
\hline \multirow[t]{2}{*}{$\mathrm{D}$} & \multirow[t]{2}{*}{22} & Control & $1389.8 \pm 320.0$ & $0 \pm 0$ & $523.0 \pm 136.0$ & $0 \pm 0$ \\
\hline & & srmCD40L $2 \mu \mathrm{g}$ & $1767.3 \pm 313.0$ & $0 \pm 0$ & $753.0 \pm 100.5$ & $0 \pm 0$ \\
\hline
\end{tabular}

Treatments with either $2 \mu \mathrm{g}$ of srmCD40L or control sera were done twice a week starting at day 1, and BMC and spleen cells from mice 7, 10, and $22 \mathrm{~d}$ after BMT were assayed as described in Methods. *Values significantly $(P<0.05)$ greater than untreated recipients.

CD40 stimulation promotes recovery of neutrophils and platelets after BMT. We then investigated if the treatment with srmCD40L could also increase the number of the mature peripheral blood cell counts after syngeneic BMT. Analysis of the complete blood count indicated that the treatment with srmCD40L resulted in a significant increase in platelet counts, as well as white blood cell (WBC) counts (Table III), reflecting the increase in the platelet and granulocyte precursors seen in the spleen. Interestingly, differential count of WBC revealed that only segmented cells (granulocytes) were increased, whereas mononuclear cells (lymphocytes) were not affected by the treatment with srmCD40L (Table III), indicating that CD40L stimulation affects mainly granulocytic and platelet precursors. Erythroid lineage cells were not significantly af-

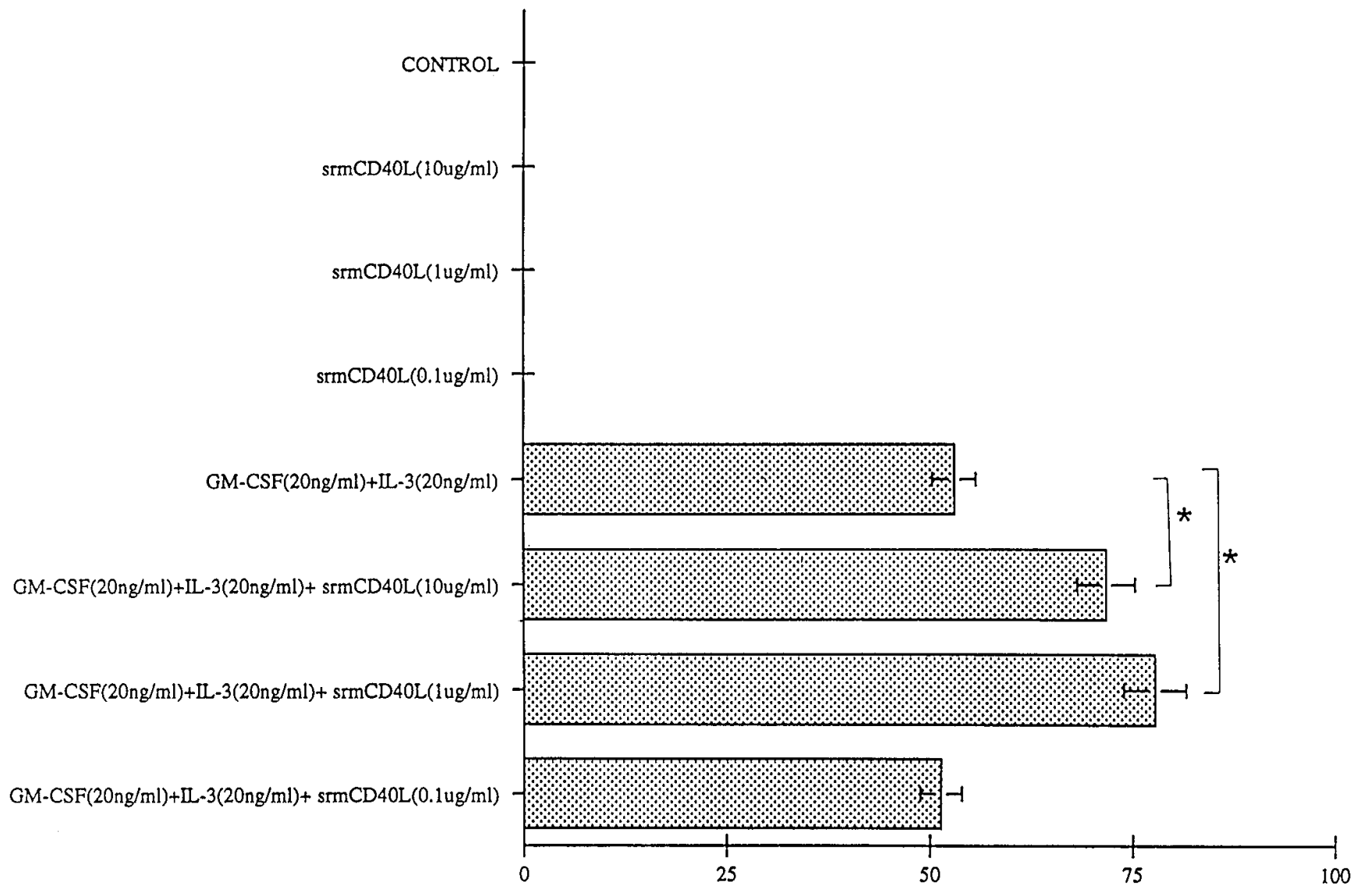

CFU-C

Figure 7. Effects of srmCD40L on CFU-C formation in vitro. The CFU-C assay was performed as described in Methods. Representative of four experiments. *srmCD40L significantly $(P<0.05)$ promoted CFU-C formation. 
Table III. Effects of srmCD40L on Peripheral Blood Cell Count

\begin{tabular}{lccc}
\hline $\begin{array}{c}\text { Day of } \\
\text { analysis }\end{array}$ & Treatment & $\begin{array}{c}\text { WBC }\left(/ \mathrm{mm}^{3}\right) \\
(\text { segmented } / \text { mononuclear })\end{array}$ & Platelet $\left(\times 10^{3} / \mathrm{mm}^{3}\right)$ \\
\hline 10 & Control & $530 \pm 60$ & $93.5 \pm 2.5$ \\
& & $(161 \pm 14 / 296 \pm 51)$ & \\
& srmCD40L 2 $\mu \mathrm{g}$ & $800 \pm 0^{*}$ & $143.3 \pm 25.8^{*}$ \\
& & $(404 \pm 34 * / 290 \pm 46)$ & \\
28 & Control & $6580 \pm 459$ & $244.0 \pm 13.9$ \\
& srmCD40L 2 $\mu \mathrm{g}$ & $6960 \pm 398$ & $291.0 \pm 42.8$ \\
\hline
\end{tabular}

After receiving BMT, either control sera or $2 \mu \mathrm{g}$ of srmCD40L were administered. The number of mature peripheral blood cell counts after syngeneic BMT was analyzed as described in Methods. $* P<0.05$.

fected (data not shown). Thus, in addition to its effects on B cell recovery after BMT, CD40 stimulation by its ligand also promotes hematopoietic reconstitution primarily affecting megakaryocytic and granulocytic lineages.

\section{Discussion}

Our data suggest that treatment with srmCD40L accelerates B cell and hematopoietic recovery in the first $2 \mathrm{wk}$ after syngeneic BMT in mice. Treatment with srmCD40L resulted in significant improvements in granulocytic and megakaryocytic lineage cell reconstitution. This is the first report showing that CD40 stimulation can have effects on both immunologic and hematologic parameters in vivo.

Despite the expression of CD40 on hematopoietic progenitor cells (24) and early B cell precursors (25), the function of CD40 in B cell development is not clear (26). One study reported that CD40 signaling enhanced or inhibited growth of human B cell precursors depending on the stage of development and costimulatory activation by interleukins; CD40 signaling promoted $\mathrm{B}$ precursors in fetal bone marrow with IL-3 or IL-4, but inhibited pro-B cell responses to IL-7 in vitro (27). Our data demonstrate that treatment with srmCD40L increased the number of $\mathrm{B}^{2} 20^{+} /$surface $\mathrm{IgM}^{-} \mathrm{B}$ cell precursors in the bone marrow, and improved the function of mature $\mathrm{B}$ cells in vivo as measured by IgM levels in vivo and LPS responsiveness in vitro ( Figs. 1-3). Although the number of B cell precursors was increased by the treatment, this increase of $B$ cell precursors did not translate into an increase in the number of mature B cells in spleen or circulation, suggesting that other costimulation such as IL-4 or IL-7 may be required for B cell maturation $(5,6,9)$. Interestingly, treatment of mice with srmCD40L also resulted in increases in $\mathrm{T}$ cell function as reflected by mitogen and anti-CD3 $\mathrm{mAb}$ responsiveness as well as activation by anti-CD3, as well as the ability to produce cytokines (i.e., IL-4) after stimulation. This is in agreement with recent reports that CD40L may also affect T cells $(28,29)$.

Stimulation via CD40 has been shown to play a critical role in $\mathrm{B}$ cell activation and differentiation responses in vitro (5-7). CD40 signaling also plays an important role in affinity maturation and isotype switching of immunoglobulin from $\operatorname{IgM}$ to $\mathrm{IgG}$ in the germinal centers under challenge with various antigens (5-7). In this report, we observed that treatment with srmCD40L increased serum IgM levels in the first 2 wk after syngeneic BMT (Fig. 3), suggesting that CD40 stimulation may augment B cell function nonspecifically. The effects of the ligand appeared most pronounced when the mice were assessed in the first $2 \mathrm{wk}$ after BMT. This may be a reflection of the tremendous myelo- and lymphopoiesis that occurs in a reconstituting animal after BMT, thus making it more sensitive to stimulation by the ligand. Indeed, we have found that administration of srmCD40L to resting mice produces far more modest effects (Reddy, V., O. Asai, W. Fanslow, D.L. Longo, and W.J. Murphy, manuscript in preparation). Alternatively, it may be that neutralizing antibodies are generated to the leucine zipper motif. We attempted to determine the effects of srmCD40L on primary immune responses using keyhole limpet hemocyanin as an immunogen, but no significant differences were observed between control mice and srmCD40Ltreated mice (data not shown). However, the optimal timing, dose, and route of administration of the ligand still needs to be determined and this may affect primary immune responses in vivo after BMT. We investigated the effects of CD40 stimulation on secondary lymphoid organ repopulation, because lymphocyte development occurs not only within bone marrow, but also within peripheral lymphoid compartments, and the recovery of immune effectors is intimately related to the reconstitution of lymph nodes (30). There have been several reports demonstrating that no germinal centers are seen in patients with hyper IgM syndrome or CD40 ligand knock-out mice (20, 31). The data presented here demonstrate that treatment with srmCD40L accelerated germinal center formation in the lymph nodes (Fig. 6, Table I) after syngeneic BMT. Thus, CD40 stimulation of B cell precursors in vivo may have functional importance, though the signaling through CD40 in B cell precursors may be only one component of a multiple signal pathway.

CD40 is also expressed on the majority of CD34 ${ }^{+}$cells in $\mathrm{BM}$ and cord blood cells, demonstrating that this antigen is not restricted to lymphoid cells (24). CD40 expression is lost during culture of $\mathrm{CD}_{3} 4^{+}$cells in the presence of IL-3, indicating transient expression early in myeloid development (24). It has been reported that CD40 knock-out mice had evidence of neutropenia only when placed in conventional housing conditions, suggesting that CD40 stimulation may play a role in granulocyte development, but can be detected only when the animals are hematopoietically stressed as after BMT or myeloablative therapy or during infection (20). We found treatment with srmCD40L after syngeneic BMT increased splenic CFU-C and segmented cells and platelets in peripheral blood (Tables II and III, Fig. 7), strongly indicating that signals through CD40 can promote granulocytic and megakaryocytic hematopoiesis and progenitor proliferation. The mechanisms could be direct or indirect, including secretion of IL-3 or GM-CSF from macrophages that also express CD40 on their surface. Further experiments are ongoing to determine the mechanisms of the hematopoietic effects of CD40 stimulation.

We have previously demonstrated that CD40 stimulation either by antibody or soluble recombinant ligand is capable of directly inhibiting the growth of aggressive histology human B cell lymphomas both in vitro and in vivo (32). Preliminary data indicate that this occurs through "activation-induced cell death" that includes the induction of apoptosis (Funakoshi, S., O. Asai, W. Fanslow, D.L. Longo, and W.J. Murphy, manuscript in preparation). Taken together with immunologic and hematologic effects of srmCD40L, it could be advantageous to ex- 
plore the use of the ligand in a clinical setting such as autologous BMT (ABMT) for relapsed aggressive histology lymphoma. Some of the problems associated with ABMT, including immune deficiency after the transplant and recurrence of the neoplasm, may be decreased with the use of srCD40L due to the pleiotropic effects of the ligand in vivo. In allogeneic BMT, one report described that antibody to CD40 ligand prevented the occurrence of graft-vs.-host disease (GVHD) (33). In T cell/B cell interaction, two specific costimulatory pathways, termed CD40 ligand:CD40 and B7:CD28, promote the activation of both cells. Blocking of CD40 stimulation can shut down this $\mathrm{T}$ cell/B cell interaction to prevent GVHD, and exogenous CD40 stimulation may, on the contrary, increase the occurrence of GVHD by activating T cells (33). More work needs to be done examining the effects of CD40 stimulation on GVHD pathology. However, the use of srCD40L may be limited to the ABMT setting. Our results suggest that treatment with srCD40L may be of clinical use for ABMT in general and the use of ABMT in the treatment of B cell lymphomas in particular.

\section{Acknowledgments}

The authors gratefully acknowledge the expert technical assistance provided by Ms. Kelli T. Czarra, Ms. Susan Turkovski-Corrales, and the Clinical Monitoring Laboratory. We thank Ms. Laura Knott and Ms. Lynn Fogle-Harrington for outstanding secretarial services.

\section{References}

1. Lum, L.G. 1990. Immune recovery after bone marrow transplantation. Bone Marrow Transplant. 4:659-675.

2. Lenarski, C. 1993. Mechanisms in immune recovery after bone marrow transplantation. Am. J. Pediatr. Hematol. Oncol. 15:49-55.

3. Brandt, S.J., W.P. Peters, S.D. Atwater, J. Kurtzberg, M.J. Borowitz, R.B. Jones, E.J. Schrall, R.C. Bast, C.J. Gilbert, and D.H. Oette. 1988. Effect of recombinant human granulocyte-macrophage colony-stimulating factor on hematopoietic reconstitution after high-dose chemotherapy and autologous bone marrow transplantation. N. Engl. J. Med. 318:869-874.

4. Clark, R., J. Strasser, S. McCabe, K. Robbins, and P. Jardieu. 1993. Insulin-like growth factor-1 stimulation of lymphopoiesis. J. Clin. Invest. 92:540548 .

5. Rousset, F., E. Garcia, and J. Banchereau. 1991. Cytokine-induced proliferation and immunoglobulin production of human B lymphocytes triggered through their CD40 antigen. J. Exp. Med. 173:705-710.

6. Splawski, J.B., S.M. Fu, and P.E. Lipsky. 1993. Immunoregulatory role of CD40 in human B cell differentiation. J. Immunol. 150:1276-1285.

7. Nonoyama, S., D. Hollenbaugh, A. Aruffo, J.A. Ledbetter, and H.D. Ochs. 1993. B cell activation via CD40 is required for specific antibody production by antigen-stimulated human B cells. J. Exp. Med. 178:1097-1102.

8. Armitage, R.J. 1994. Tumor necrosis factor receptor superfamily members and their ligands. Curr. Opin. Immunol. 6:407-413.

9. Alderson, M.D., R.J. Armitage, T.W. Tough, L. Strockbine, W.C. Fanslow, and M.K. Spriggs. 1993. CD40 expression by human monocytes: regulation by cytokines and activation of monocytes by the ligand for CD40. J. Exp. Med. 178:669-674.

10. Caux, C., C. Massacrier, B. Vanbervliet, B. Dubois, C.V. Kooten, I. Durand, and J. Banchereau. 1994. Activation of human dendritic cells through CD40 cross-linking. J. Exp. Med. 180:1263-1272.

11. Stamenkovic, I., E.A. Clark, and B. Seed. 1989. A B-lymphocyte activation molecule related to the nerve growth factor receptor and induced by cytokines in carcinomas. EMBO (Eur. Mol. Biol Organ.) J. 8:1403-1410.

12. Nonoyama, S., D. Hollenbaugh, A. Aruffo, J.A. Ledbetter, and H.D. Ochs. 1993. B cell activation via CD40 is required for specific antibody production by antigen-stimulated human B cells. J. Exp. Med. 178:1097-1102.

13. Splawski, J.B., S.M. Fu, and P.E. Lipsky. 1993. Immunoregulatory role of CD40 in human B cell differentiation. J. Immunol. 150:1276-1285.

14. Armitage, R.J., C.R. Maliszewski, M.R. Alderson, K.H. Grabstein, M.K. Spriggs, and W.C. Fanslow. 1993. CD40L: a multi-functional ligand. Semin. Immunol. 5:401-411.

15. Armitage, R.J., W.C. Fanslow, L. Strockbine, T.A. Sato, K.Y. Clifford, S.D. Gimpel, T. Davis-Smith, C.R. Maliszewski, E.A. Clark, C.A. Smith, et al. 1992. Molecular and biological characterization of a murine ligand for CD40. Nature (Lond.). 357:80-82.

16. Aruffo, A., M. Farrington, D. Hollenbaugh, X. Li, A. Milatovich, S. Nonoyama, J. Bajorath, L.S. Grosmaire, R. Stenkamp, M. Neubauer, et al. 1993. The CD40 ligand, gp39, is defective in activated T cells from patients with X-linked hyper-IgM syndrome. Cell. 72:291-300.

17. Cutler, R.C., R.J. Armitage, M.E. Conley, H. Rosenblatt, N.A. Jenkins, N.G. Copeland, M.A. Bedell, S. Edelhoff, C.M. Disteche, D.K. Simoneaux, W.C. Fanslow, J. Belmont, and M.K. Spriggs. 1993. CD40 ligand gene defects responsible for X-linked hyper-IgM syndrome. Science (Wash. DC). 259:990993.

18. Foy, T.M., D.M. Shephard, F.H. Durie, A. Aruffo, J.A. Ledbetter, and R.J. Noelle. 1993. In vivo CD-40-gp39 interactions are essential for thymusdependent humoral immunity. II. Prolonged supression of the humoral immune response by an antibody to the ligand for CD40, gp39. J. Exp. Med. 178: $1567-1575$.

19. Van den Eertwegh, A.R., R. Noelle, M. Roy, D. Shepherd, A. Aruffo, J. Ledbetter, W. Boersma, and E. Claasen. 1993. In vivo CD40-gp39 interactions are essential for thymus- dependent humoral immunity. I. In vivo expression of CD40 ligand, cytokines, and antibody production delineates sites of cognate T-B cell interactions. J. Exp. Med. 178:1555-1565.

20. Kawabe, T., T. Naka, K. Yoshida, T. Tanaka, H. Fujiwara, S. Suematsu, N. Yashida, T. Kishimoto, and H. Kikutani. 1994. The immune responses in CD40-deficient mice: impaired immunoglobulin class switching and germinal center formation. Immunity. 1:167-178.

21. Spriggs, M.K., R.J. Armitage, L. Strockbine, K.N. Clifford, B.M. Macduff, T.A. Sato, C.R. Maliszewski, and W.C. Fanslow. 1992. Recombinant human CD40 ligand stimulates B cell proliferation and immunoglobulin E secretion. J. Exp. Med. 176:1543-1550.

22. Maliszewski, C.R., K.H. Grabstein, W.C. Fanslow, R.J. Armitage, M.K Spriggs, and T.A. Sato. 1993. Recombinant CD40 ligand stimulation of murine $\mathrm{B}$ cell growth and differentiation: cooperative effects of cytokines. Eur. J. Immunol. 23:1044-1049.

23. Armitage, R.J., B.M. Macduff, M.K. Spriggs, and W.C. Fanslow. 1993. Human B cell proliferation and Ig secretion by recombinant CD40 ligand are modulated by soluble cytokines. J. Immunol. 150:3671-3680.

24. Saeland, S., V. Duvert, C. Caux, D. Pandrau, C. Favre, A. Valle, I. Durand, P. Charbord, J. Vries, J. Banchereau. 1992. Distribution of surface-membrane molecules on bone marrow and cord blood $\mathrm{CD} 34^{+}$hematopoietic cells. Exp. Hematol. (Charlottesv.). 20:24-33.

25. Law, C.L., B. Wormann, T.W. LeBien. 1990. Analysis of expression and function of CD40 on normal and leukemic human B cell precursors. Leukemia (Baltimore). 4:732-738.

26. Renard, N., V. Duvert, D. Blanchard, J. Banchereau, S. Saeland. 1994 Activated $\mathrm{CD}^{+}$cells induce CD40-dependent proliferation of human B cell precursors. J. Immunol. 152:1693-1701.

27. Larson, A.W., and T.W. LeBien. 1994. Cross-linking CD40 on human B cell precursors inhibits or enhances growth depending on the stage of development and IL costimulus. J. Immunol. 153:584-594.

28. Yang, Y., and J.M. Wilson. 1996. CD40 Ligand-dependent T cell activation: requirement of B7-CD28 signaling through CD40. Science (Wash. DC). 273:1862-1864.

29. Grewal, I.S., H.G. Foeller, K.D. Grewal, J. Xu, F. Hardardottir, J.L. Baron, C.A. Janeway, and R.A. Flavell. 1996. Requirement for CD40 ligand in costimulation induction, T cell activation, and experimental allergic encephalomyelitis. Science (Wash. DC). 273:1864-1867.

30. Sackstein, R. 1993. Physiologic migration of lymphocytes to lymph nodes following bone marrow transplantation: role in immune recovery. Semin. Oncol. 20:34-39.

31. Xu, J., T.M. Foy, J.D. Laman, E.A. Elliot, J.J. Dunn, T.J. Waldschmidt, J. Elsemore, R.J. Noelle, and R.A. Flavell. 1994. Mice deficient for the CD40 ligand. Immunity. 1:423-431.

32. Funakoshi, S., D.L. Longo, M. Beckwith, D.K. Conley, G. Tsarfaty, I. Tsarfaty, R.J. Armitage, W.C. Fanslow, M.K. Spriggs, and W.J. Murphy. 1994. Inhibition of human B cell lymphoma growth by CD40 stimulation. Blood. 83: 2787-2793.

33. Durie, F.H., A. Aruffo, and R.J. Noelle. 1994. Antibody to the ligand of CD40, gp39, blocks the occurrence of acute and chronic forms of graft-vs-host disease. J. Clin. Invest. 94:1333-1338. 